\title{
THE MAHILA SAMAKHYA PROGRAM: EMPOWERING EDUCATION FOR WOMEN'S EQUALITY IN INDIAN DISADVANTAGED COMMU- NITIES AND RURAL AREAS
}

\author{
Autora: BARBERILLO NUALART, Gemma \\ University of Kent. Department of Politics and International Relations. \\ gbn4@kent.ac.uk
}

\begin{abstract}
In India the women's movement and the government have done much to ameliorate women's education and to build the gender gap. However, it is argued that India still has much gender inequalities embedded in society and, as a consequence, in education and that there is much work to be done in terms of implementation. An alternative form of education, the Mahila Samakhya Program, was launched in India in 1988 for the education and empowerment of women in rural areas and disadvantaged communities in order to achieve equality. The Mahila Sanghas or women's collectives were created to provide a space for women and girls to meet, reflect, ask questions and express their thoughts.
\end{abstract}

This article argues for the implementation of an empowering education, apart from the formal education, to help women and girls overcome inequalities especially in education. It aims to prove how this empowering education increases education for poor women in rural areas, especially for girls. It examines the quality and results of the existing Mahila Samakhya program analyzing the empowering process. The case study will be the Indian state of Bihar and two theories of empowerment will be applied.

\section{Key words}

Gender, women, equality, education, empowerment, India.

\section{Introduction: Women's Empowerment}

Empowering education (also called gender-training or transformatory form of education), in particular the Mahila Samakhya program in India, is a new form of education that has given women the way to address the access to education barriers and to have enough empowerment to be ready to participate in education. This new form of education does not consist of a mechanical transfer of knowledge and skills, but rather a social analysis, awareness-building, critical reflection and organizational skills for mobilization. This has enabled women to move from a passive acceptance of their situation to a collective action and control of their lives.
The article argues for the implementation of this empowering education to abolish women's inequalities in India. It will prove that this new form of education can improve their lives and increase education for poor women in rural areas and disadvantaged communities, analysing the results of the Mahilsa Samakhya program in the state of Bihar.

This analysis is important to the field of education to women because it brings consciousness about the real problem of education. Sometimes, uneducated women are not aware of the opportunities they have. Even girls who manage to go to school drop out before finishing. Education in India is even argued to emphasize the 
gender gap through different ways, such as images in textbooks, stereotypical roles given to girls and boys, perceptions of teachers that reinforce patriarchy, etc. The article will see the importance of values and believes within a society that impedes women to fully develop and will look for the process through which women can change and embrace their opportunities in education and in other aspects of their daily lives.

The theoretical framework both Elisheva Sadan's "Empowerment and Community Practice" and the "Women Empowerment Approach: A methodological Guide Research" will be applied. They analyse the change of mindset and the mobilization of women participating in the Mahila Samakhya program in Bihar and its impact on the education of women and girls.

The term "empowerment" comes from the feminist popular theory and it appeared in India through the women's movement in the 1980s. This term replaced the previous ones such as "women's welfare", "women's development" and "women's up-lifting” that were used to express the same concept. Empowerment entered the field of gender equality in India because of the feminists that challenged patriarchy, the government policies and the aid agencies. By the 1990s, the term empowerment was already wildly used. ${ }^{1}$

Elisheva Sadan in his book "Empowerment and Community Practice" ${ }^{2}$ sets an empowerment theory inspired by other theories. Elisheva Sadan searches for an empowerment theory and she describes empowerment as follows:

Empowerment is a process of transition from a state of powerlessness to a state of relative control over one's life, destiny and environment. This transition can manifest itself in an improvement in the perceived ability to control, as well as in an improvement in the actual ability to control. ${ }^{3}$

Therefore, empowerment is a transition from a passive situation (lack of self-worth, self-blame, etc.) to a

\footnotetext{
${ }^{1}$ Batliwala, S. (2007). Taking the Power out of Empowerment: An Experiential Account. Development in Practice, 17(4/5), 559.

${ }_{2}$ Sadan, E. (2004). Chapter 3: A Theory of Empowerment. In: Sadan, E. ed. Empowerment and Community Practice. [Online]. Tel Aviv: Hakibutz Hameuchad. 137-169. Available from: http://www.mpow.org/ [Accessed 30 June 2012].

${ }^{3}$ Sadan, E. (2004). Chapter 3: A Theory of Empowerment. In: Sadan, E. ed. Empowerment and Community Practice. [Online]. Tel Aviv: Hakibutz Hameuchad. 144. Available from: http://www.mpow.org/ [Accessed 30 June 2012].
}

more active situation of control. She argues that powerlessness comes from a social process called disempowerment. The empowerment process aims to influence the oppressed human agency and the social structure. $^{4}$

Powerlessness is about losing control about one's life and how it influences the lives and futures of the individuals and the fate of the entire community. Elisheva argues that the democratic values provide a good social structure for empowerment processes because there are structures and systems within the democratic system that create powerlessness. She states that "the democratic system provides a mechanism, a legitimation, and a moral endorsement for extreme and structured powerlessness". 5

Elisheva argues that the society has direct and indirect ways of disempowerment, the power barriers. The indirect power barriers are the ones that are present when the person is growing up and they are transmitted to the child or teenager by other important persons in his/her life. These are the authoritative resources that the society provides by its organization and they are considered the most influential. The direct power barriers are the allocative resources and are implemented against the individual directly through the practices of social systems. The authoritative and allocative resources integrate the direct and indirect power barriers into the structure that give them legitimation. ${ }^{6}$ The abolition of a barrier accelerates the progress and makes it easier for changes to come in regards of the material resources and the organizational resources. $^{7}$

Elisheva argues that empowerment is composed of:

- The process of individual empowerment (micro level) is a process of increasing control over the environment to change from a state of powerlessness to a state of power.

\footnotetext{
${ }^{4}$ Sadan, E. (2004). Chapter 3: A Theory of Empowerment. In: Sadan, E. ed. Empowerment and Community Practice. [Online]. Tel Aviv: Hakibutz Hameuchad. 144. Available from: http://www.mpow.org/ [Accessed 30 June 2012].

${ }^{5}$ Sadan, E. (2004). Chapter 3: A Theory of Empowerment. In: Sadan, E. ed. Empowerment and Community Practice. [Online]. Tel Aviv: Hakibutz Hameuchad. 164. Available from: http://www.mpow.org/ [Accessed 30 June 2012].

${ }^{6}$ Sadan, E. (2004). Chapter 3: A Theory of Empowerment. In: Sadan, E. ed. Empowerment and Community Practice. [Online]. Tel Aviv: Hakibutz Hameuchad. 154-155. Available from: http://www.mpow.org/ [Accessed 30 June 2012].

7 Sadan, E. (2004). Chapter 3: A Theory of Empowerment. In: Sadan, E. ed. Empowerment and Community Practice. [Online]. Tel Aviv: Hakibutz Hameuchad. 156. Available from: http://www.mpow.org/ [Accessed 30 June 2012].
} 
- The process of community empowerment (macro level) is a social change process which consists of organizing and creating a community that suffers the same discrimination and that will learn to control the environment together. ${ }^{8}$

Elisheva argues that individual empowerment creates a possibility of community empowerment and the other way round. She also argues that the empowerment process is composed of a duality of structure. She argues that empowerment potential does not only exist in terms of people's personal resources and abilities, but also in terms of the rules and regulations of the social structure. There is a connection between social structure and human agency that explains the way community empowerment contributes to individual empowerment. ${ }^{9}$ Empowerment is the power of the individual person or the collective to interpret the structures of control within society and change them through behavior. Brief, empowerment creates a change in human behavior and in the social structure. ${ }^{10}$ The "Women Empowerment Approach: A methodological Guide Research"11 describes empowerment as directly related to the notion of power. It argues that there are multiple "powers". Therefore, it considers empowerment to be a process to acquire "power" individually and collectively. The guide argues that empowerment is seen as a process, a construction of identity, both individual and collective. She divides the empowerment process into four levels of power:

- Power over: it means having power over someone or something, domination or subordination.

- Power to: which includes the ability to make decisions, have authority and find solutions to

\footnotetext{
${ }^{8}$ Three types of empowerment from: Sadan, E. (2004). Chapter 3: A Theory of Empowerment. In: Sadan, E. ed. Empowerment and Community Practice. [Online]. Tel Aviv: Hakibutz Hameuchad. 145. Available from: http://www.mpow.org/ [Accessed 30 June 2012].

9 Sadan, E. (2004). Chapter 3: A Theory of Empowerment. In: Sadan, E. ed. Empowerment and Community Practice. [Online]. Tel Aviv: Hakibutz Hameuchad. 149. Available from: http://www.mpow.org/ [Accessed 30 June 2012].

${ }^{10}$ Sadan, E. (2004). Chapter 3: A Theory of Empowerment. In: Sadan, E. ed. Empowerment and Community Practice. [Online]. Tel Aviv: Hakibutz Hameuchad. 150-151. Available from: http://www.mpow.org/ [Accessed 30 June 2012].

${ }^{11}$ Commission on Women and Development. (2007). The women empowerment approach, a methodological guide. [Online]. Vrouwen \& Ontwikkeling / Femmes \& Development. 1-43. Available from:

http://www.atol.be/docs/publ/gender/women_empowerment_approa ch_CVO.pdf. [Accessed 22 June 2012].
}

problems. It refers to intellectual abilities as well as economic means.

- Power with: social or political power which highlights the notion of common purpose or understanding, as well as the ability to get together to negotiate and defend a common goal (individual and collective rights, political ideas such as lobbying, etc.). Collectively, people feel they have power when they can get together and unite in search of a common objective, or when they share the same vision;

- Power within: this notion of power refers to self-awareness, self-esteem, identity and assertiveness (knowing how to be). It refers to how individuals, through self-analysis and internal power, can influence their lives. ${ }^{12}$

The methodological approach argues the empowerment process is a means to take opportunities to seize power and to change the environment. It argues, therefore, that empowerment operates on two levels:

- In relation to its capacity for personal change

- $\quad$ In relation to political and social change. ${ }^{13}$

The guide sets 4 aspects of empowerment:

- Assets (power to): greater economic power in terms of resources as well as better health, more time, access to certain services, etc.

- Knowledge and know-how (power to): This means having more knowledge or skills for the person or the community to make the most of the opportunities that arise and to know how to mobilize.

- Will (internal power/power within): This refers to power within the person (values and fears, self-confidence and self-perception) and the ability to control one's future.

- Capacity (internal power and power with): This means having the opportunity to make

\footnotetext{
${ }^{12}$ Commission on Women and Development. (2007). The women empowerment approach, a methodological guide. [Online]. Vrouwen \& Ontwikkeling / Femmes \& Development. 10. Available from: http://www.atol.be/docs/publ/gender/women_empowerment_approa ch_CVO.pdf. [Accessed 22 June 2012].

${ }_{13}$ Commission on Women and Development. (2007). The women empowerment approach, a methodological guide. [Online]. Vrouwen \& Ontwikkeling / Femmes \& Development. 11. Available from: http://www.atol.be/docs/publ/gender/women_empowerment_approa ch_CVO.pdf. [Accessed 22 June 2012].
} 
one's decisions and be free to act using one's resources (assets, knowledge and will). ${ }^{14}$

It sets 4 steps of the process:

- Baseline: the situation before a program is launched, in terms of resources (economic, human, and socio-political).

- Program input: what the program contributes in terms of resources (economic, human, and socio-political).

- Results of the program: the results during and after the program, in terms of greater choice: at individual level (life plans) and at society level (gender equality)

- Impact of the program: the changes the program has brought about in terms of quality of life and social justice.

Both theories of empowerment agree in that the concept of empowerment is acquiring power, which means going from a passive situation of lack of selfworth to a situation of control over one's life. It is a transition from powerlessness to more control in life as a change in both human activity and the social structure. Powerlessness, as Elisheva states, is a social phenomenon that has structural aspects which are rooted in the disempowering practices that originate in the social systems, mostly in democratic regimes.

Both articles argue that there are different types of empowerment, mostly individual and collective. The two articles agree in that individual and collective empowerment go together one with the other. In most of the literature, I have found that grassroots groups are almost centered in collective empowerment rather than individual empowerment, but I think that one cannot exist without the other.

In order for the community to develop a sense of responsibility, commitment and ability to care for collective survival and the change of the environment to have better quality of life, in particular between men and women, a woman has to change the values and believes she has, her goals, her life-style, the understanding of her problems and the aim to change the social struc-

\footnotetext{
${ }^{14}$ Commission on Women and Development. (2007). The women empowerment approach, a methodological guide. [Online]. Vrouwen \& Ontwikkeling / Femmes \& Development. 13. Available from: http://www.atol.be/docs/publ/gender/women_empowerment_approa ch_CVO.pdf. [Accessed 22 June 2012].
}

tures to influence her life. In my opinion, this process embraces both an individual and collective empowerment. One does not exist without the other.

Empowerment is a bottom-up process rather than a top-down one, therefore, understanding empowerment means understanding that development agencies do not empower women but rather women must empower themselves. That is why a collective empowerment, from my point of view, cannot be detached from an individual empowerment. ${ }^{15}$

Using these two theoretical frameworks, I will analyze the empowerment process of the Mahila Samakhya program in Bihar to argue if the empowering education in fact increases education for women and girls in the rural areas and the poorest communities. The analysis will be based in qualitative information (personal experiences) and summarizing all the theory used before based mainly this time with the Elisheva theory. Although some quantitative data will be used in this article, I think that personal experiences can explain better social changes than quantitative data, especially in such a vast country as India where the progress is different in every part of the country.

By using both theoretical frameworks, the process of the Mahila Samakhya program will be more understandable and it will be easier to prove my argument. I think that both theories share the same principles but they complement each other in some areas and they provide a much complex analysis framework.

\footnotetext{
${ }^{15}$ Oxaal, Z. and Baden, S. (1997). Gender and empowerment: definitions, approaches and implications for policy [Online]. University of Sussex: Bridge (development-gender). Available from: http://generoyambiente.com/arcangel2/documentos/376.pdf [Accessed 21 June 2012].
} 


\section{Women's education in India}

In regards of gender equality, the Indian situation is very contradictory. There is a contrast between what is on paper and what is done in practice. On the one hand, the state has passed much legislation to protect women. However, there is poor implementation. Women's rights are avoided in administrative and judicial terms. Even the state is the main upholder of patriarchal institutions. ${ }^{16}$

Providing quality education for all in India has not been possible yet. ${ }^{17}$ India wants to reach this goal as soon as possible mainly because the government committed itself to the Dakar Framework for Action for providing Education for All by 2015. The Dakar Framework of Action gave six specific goals to be achieved by all countries. The National Plan of Action for Education for All (2002) in India was created to reach these goals. ${ }^{18}$ UNESCO has been issuing an annual review about the progress made towards the goal of EFA through the Global Monitoring Report. These reviews are not very positive in India because there is around $65 \%$ of adult literacy rate, with around 350 million adult illiterates in the country. This can be really discouraging and a major concern since one sixth of the world population lives in India. ${ }^{19}$

\footnotetext{
${ }^{16}$ Sen, S. (2000). Towards a Feminist Politics? The Indian Women's Movement in Historical Perspective. [Online]. Working Paper Series No. 9. The World Bank Development Research Group. Available from:

http://www.google.com/url?sa=t\&rct=j\&q=towards\%20feminist $\% 20$ poli-

tics\&source=web\&cd=1\&ved=0CFcQFjAA\&url=http $\% 3 \mathrm{~A} \% 2 \mathrm{~F} \% 2 \mathrm{~F}$ cite-

seerx.ist.psu.edu\%2Fviewdoc\%2Fdownload\%3Fdoi\%3D10.1.1.195. 9810\%26rep\%3Drep1\%26type\%3Dpdf\&ei=iKzIT7LTHcOXOqyzs AY\&usg $=$ AFQjCNEESalc1jHZUCPYnwnEbbt9efTEGA [Accessed 20 June 2012].

${ }^{17}$ Ramachandran, V. (2009). Education for all - mid decade assessment. Towards Gender Equality in Education. [Online]. New Delhi: National University of Educational Planning and Administration New Delhi. Available from: http://www.educationforallinindia.com/Towards-Gender-Equalityin-Education-1.pdf [Accessed 15 June 2012].

${ }^{18}$ Ramachandran, V. (2009). Education for all - mid decade assessment. Towards Gender Equality in Education. [Online]. New Delhi: National University of Educational Planning and Administration New Delhi. Available from: http://www.educationforallinindia.com/Towards-Gender-Equalityin-Education-1.pdf [Accessed 15 June 2012].

${ }^{19}$ Ramachandran, V. (2009). Education for all - mid decade assessment. Towards Gender Equality in Education. [Online]. New Delhi: National University of Educational Planning and Administration New Delhi. $\quad$ Available r from: http://www.educationforallinindia.com/Towards-Gender-Equalityin-Education-1.pdf [Accessed 15 June 2012].
}

The women's movement in India started in the 1920s, building on the 19th century social reform movement. The women's movement progressed during the period of nationalism and the freedom struggle. Among the many achievements of the movement, the most significant were the constitutional guarantees of equal rights for women and universal adult suffrage in independent India. However, these guarantees did little to bring about social and material change in the lives of most Indian women. ${ }^{20}$

A new women's movement emerged in the 1970s. This contemporary women's movement moved beyond the traditional concerns to a wide range of issues. It has played an important role in developing programs for poor women and in creating grassroots organizations for women's empowerment. It has contributed to bringing gender issues to the main agenda and it has pressured the state to enforce progressive legislation and gender-sensitive policies and programs for poor and rural women. ${ }^{21}$ The Mahila Samakhya program is one of the examples. Therefore, the last decades of the contemporary women's movements in India have had some positive advances after a long time of passivity. ${ }^{22}$

Despite the struggle from the women's movement, patriarchy remains deeply entrenched in India, influencing the structure of its political and social institutions and determining the opportunities for women. ${ }^{23}$

\footnotetext{
${ }^{20}$ Sen, S. (2000). Towards a Feminist Politics? The Indian Women's Movement in Historical Perspective. [Online]. Working Paper Series No. 9. The World Bank Development Research Group. Available from:

http://www.google.com/url?sa=t\&rct=j\&q=towards $\% 20$ feminist $\% 20$ poli-

tics\&source $=$ web\&cd $=1 \& v e d=0 C F c Q F j A A \& u r l=h t t p \% 3 A \% 2 F \% 2 F$ cite-

seerx.ist.psu.edu\%2Fviewdoc\%2Fdownload\%3Fdoi\%3D10.1.1.195. 9810\%26rep\%3Drep1\%26type\%3Dpdf\&ei=iKzIT7LTHcOXOqyzs AY\&usg=AFQjCNEESalc1jHZUCPYnwnEbbt9efTEGA [Accessed 20 June 2012].

${ }_{21}$ Patel, I. (1998). The contemporary women's movement and women's education in India. International Review Education, 44(23), 156-157.

${ }_{22}$ Sharma, K. (1989). Shared aspirations, fragmented realities contemporary women's movement in India its dialects and dilemmas [Online]. Available from: http://www.cwds.ac.in/OCPaper/SharedAspirationsKS.pdf. [Accessed 26 February 2012].

${ }^{23}$ Sen, S. (2000). Towards a Feminist Politics? The Indian Women's Movement in Historical Perspective. [Online]. Working Paper Series No. 9. The World Bank Development Research Group. Available from:

http://www.google.com/url?sa=t\&rct=j\&q=towards $\% 20$ feminist $\% 20$
} 
Fewer girls than boys attend school. Even when girls are enrolled, only few girls manage to stay and complete school. Most girls who drop out of school are working at home and on fields. Women's work is undervalued and unrecognized and women generally earn a far lower wage than men. Most women do not own property and they increasingly suffer of violence. The deeply ingrained system of patriarchy describes women's identity and role. ${ }^{24}$ Therefore, the inequalities those girls daily face in society and, as a consequence, in education are many. Many girls are excluded because of their gender but they also face other barriers, making it more difficult for them to enroll, complete primary school and continue on the secondary school.

The government has enhanced many policies and strategies to protect women and bridge gender and social gaps. The fact is that these are good policies, programs and initiatives, but they are not well implemented and there is little social and political pressure to hear the system to eliminate gender and social differences and ensure all children and especially girls have all access to good quality education. The women's movement, as we have seen before, has made some pressure and has tried to influence the government in terms of women's education, but it has been really weak many times to influence it. ${ }^{25}$

However, India is such a vast country that, from my point of view, it is not possible to generalize about certain issues. Some states may have achieved remarkable progress in terms of education and almost achieving universal participation of children in elementary education, whereas other states may have remained far from the goal.

poli-

tics\&source $=$ web\&cd $=1 \&$ ved $=0$ CFcQFjAA\&url $=\mathrm{http} \% 3 \mathrm{~A} \% 2 \mathrm{~F} \% 2 \mathrm{~F}$

cite-

seerx.ist.psu.edu\%2Fviewdoc\%2Fdownload\%3Fdoi\%3D10.1.1.195. 9810\%26rep\%3Drep1\%26type\%3Dpdf\&ei=iKzIT7LTHcOXOqyzs AY\&usg=AFQjCNEESalc1jHZUCPYnwnEbbt9efTEGA [Accessed 20 June 2012].

${ }^{24}$ Jain, S. (2003). Gender equality in education. Community based initiatives in India. [Online]. Education for All Global Monitoring Report 2003/2004. Available from: http://ddpext.worldbank.org/EdStats/INDgmrpap03a.pdf [Accessed 3 June 2012].

${ }^{25}$ Ramachandran, V. (2009). Education for all - mid decade assessment. Towards Gender Equality in Education. [Online]. New Delhi: National University of Educational Planning and Administration New Delhi. Available from: http://www.educationforallinindia.com/Towards-Gender-Equalityin-Education-1.pdf [Accessed 15 June 2012]. 


\section{The Mahila Samakhya Karnataka Program}

"Mahila" means "women" and "Samakhya" is a compound of the Sanskrit words, "sama" meaning "equal", and "akhya" meaning to be valued or weighed. ${ }^{26}$ The Mahila Samakhya Karnataka program was initiated by the Government, Ministry of Human Resource Development, in 1998 in order to transform the goals of the National Policy on Education into a concrete program for the education and empowerment of women of marginalized groups in rural areas. In the beginning it was implemented in three states (Karnataka, Gujarat and Uttar Pradesh). ${ }^{27}$ Now it is being implemented in 60 districts in 10 states. ${ }^{28}$ It was awarded the honorary literacy award of UNESCO in 2001. ${ }^{29}$

The Mahila Samakhya program has two main objectives:

- It offers an example of the importance of empowerment of women as a prerequisite to facilitate greater inclusion of women and their daughters into education.

- Further, it provides an alternative paradigm to women's mobilisation and empowerment. ${ }^{30}$

Unlike the conventional approach to education, empowering education does not only consist of a transfer of knowledge and skills. It departs from the ideas and information that women already have, without imposing them new ideas. It is more an awareness-building, social analysis, critical reflection and organization skills for mobilization.

\footnotetext{
${ }^{26}$ Subramaniam, M. (2011). Grassroots groups and poor women's empowerment in rural India. International Sociology. 27(1) 74.

${ }^{27}$ Jain, S. (2003). Gender equality in education. Community based initiatives in India. [Online]. Education for All Global Monitoring Report 2003/2004. Available from: http://ddpext.worldbank.org/EdStats/INDgmrpap03a.pdf [Accessed 3 June 2012].

${ }^{28}$ Jandhyala, K. (2003). Empowering Education: the Mahila Samakhya experience. UNESCO, 1.

${ }_{29}^{29}$ Mahila Samakhya (Education for Women's Equality) Programme Ministry of Human Resource Development (Department of Elementary Education \& Literacy). [Online]. Available from: http://www.google.com/url?sa=t\&rct=j\&q=mahila $\% 20$ samakhya $\% 2$ 0 (education $\% 20$ for $\% 20$ women $\%$ E2\% $\% 0 \% 99 \mathrm{~s} \% 20$ equality) $\% 20$ prog ramme \&source $=$ web $\&$ cd $=1 \&$ sqi $=2 \&$ ved $=0$ CF0QFjAA\&url $=$ http $\% 3$ $\mathrm{A} \% 2 \mathrm{~F} \% 2 \mathrm{Fssa}$.nic.in\%2Fgirls-education $\% 2$ Fmahila-samakhyascheme\%2F10THPLANMSL.pdf\&ei=OTvST7O1O4m3hAe03YjIA w\&usg=AFQjCNEi_TD4JH9eBDmy03ONBNIHm9u0vQ [Accessed 8 June 2012].

${ }^{30}$ Jandhyala, K. (2003). Empowering Education: the Mahila Samakhya experience. UNESCO, 1.
}

Empowerment is not, however, simply a change of mindset. It also involves collective action for transforming structures that subordinate women (mobilization). ${ }^{31}$ Educational strategies for women's empowerment are often linked with organizational strategies for mobilization. In other words, the program mobilizes women into sanghas (also called women's collectives or women's groups) from the most disadvantaged communities in rural areas. In this process, women move from a passive state, where they accept their subordination, to one where they become active in their own transformation. ${ }^{32}$ The aim is to create a nonthreatening environment through women's groups for poor women to learn (in most of the cases for the first time). ${ }^{33}$

Sangha membership comprises mainly "dalits", who are the lower caste of India. Caste and religion form the structure of villages. Dalit women struggle against great inequalities. Discrimination is a way to control and to constrain them in their lives. Sanghas facilitate articulation as a means to recognize oppression and challenge power, which contributes to the politicalcultural empowerment of its members. ${ }^{34}$

The sanghas basically deal with the following issues: education of children especially girls and abolition of child labor (the program's main impact is in this area); seeking and obtaining literacy and numeracy skills for themselves; health (women's work, nutrition, health status, etc.); livelihood issues, savings and credit, access to government resources, natural resource management; participation in local governance (panchayat elections); ensuring effective delivery and functioning of government services and structures (education, nursery, etc.); articulating their concerns and tackling

\footnotetext{
31 Patel, I. (1998). The contemporary women's movement and women's education in India. International Review Education, 44(23), 167.

${ }^{32}$ Jain, S. (2003). Gender equality in education. Community based initiatives in India. [Online]. Education for All Global Monitoring Report 2003/2004. Available from: http://ddpext.worldbank.org/EdStats/INDgmrpap03a.pdf [Accessed 3 June 2012].

33 Patel, I. (1998). The contemporary women's movement and women's education in India. International Review Education, 44(23), 168.

${ }^{34}$ Subramaniam, M. (2011). Grassroots groups and poor women's empowerment in rural India. International Sociology. 27(1) 79. Also see: Govinda, R. (2006). The Politics of the Marginalised: Dalits and Women's Activism in India. Gender and Development, 14 (2), 181190 .
} 
social issues like alcoholism, violence against women/child marriage, challenging and changing traditions that discriminate against women. ${ }^{35}$

The Mahila Samakhya program aims to make education possible for poor rural women. The project assumption is that women should first question gender stereotypes by the community, which are the reason for women's non-access to the world of education. Then, facilitating access through questioning is the first step. ${ }^{36}$

\subsection{The experience in the state of Bihar}

This article will argue how a new form of transformative education by grassroots groups, empowering education, in Bihar is used to empower women and girls and how it increases the literacy rates, education enrolment and participation in some areas. Through this case study I will prove the argument that Mahila Samakhya program changes mindsets and fosters mobilization towards education, especially for girls.

\subsubsection{Initial situation}

This is the equivalent of the baseline step as described by the "Methodological Guide of the Women Empowerment Approach". Here the initial situation for most women and girls in Bihar called baseline is analyzed looking upon the difficulties in terms of economic, human and socio-political resources to have access to school since monitoring a process of change and assessing the results implies understanding the initial situation. $^{37}$

Bihar is situated in the north-eastern part of India. It is mostly a rural state and a growing population. In the census in 2001, there were almost 83 million people. Therefore, Bihar is the largest state in India in terms of population size. Society in Bihar is agrarian, feudal and they live under very tough circumstances. Society is also rooted in traditional believes and superstitions and

\footnotetext{
${ }^{35}$ Jandhyala, K. (2003). Empowering Education: the Mahila Samakhya experience. UNESCO, 6-11.

36 Jain, S. (2003). Gender equality in education. Community based initiatives in India. [Online]. Education for All Global Monitoring Report 2003/2004. Available from: http://ddpext.worldbank.org/EdStats/INDgmrpap03a.pdf [Accessed 3 June 2012].

${ }^{37}$ Commission on Women and Development. (2007). The women empowerment approach, a methodological guide. [Online]. Vrouwen \& Ontwikkeling / Femmes \& Development. 18. Available from: http://www.atol.be/docs/publ/gender/women_empowerment_approa ch_CVO.pdf. [Accessed 22 June 2012].
}

there is no will to change. Gender bias against women is strong. In the school enrolment there is a disadvantage for female and lower cast children, especially girls. This leads to the lowest literacy levels of the entire country. The overall literacy rate in Bihar in 2001 was $48 \%$ compared to the national literacy rate of $65 \%$. The female literacy rate was of $34 \%$ against the national female literacy rate of $54 \%$. $^{38}$

Analyzing their situation in Bihar through a survey on girl's education we encounter the following human, economic and socio-political problems in education.

In terms of social resources, there are many differences between boys and girls because they do not have the same opportunities. In Bihar, like in other states of India, girls are given less importance than boys in the field of education. Girls are involved in household work and they are mainly involved in the family. The survey states that among girls that were asked about the main barriers in education, 40\% answered that they did not attend school due to household work. They said that the parents involve them to take care of the siblings, to contribute in household work and to support family in agricultural work or different activities that generate income. Therefore, there is a lack of resources in society and Mahila Samakhya is argued to change those opportunities. ${ }^{39}$

In terms of economic resources, in this survey it is been argued that girls are not able to go to school for economic reasons but also because boys are considered a better economic investment than girls. Parents think that girls will leave the house after marriage for good; therefore, they prefer involving the girls in agricultural work, for instance, so that boys can continue studying. The reason of all this is that boys will be the ones that earn money for the family later on. ${ }^{40}$

Finally, in terms of human resources, such as selfperception and self-confidence, their will to commit and contribute to education, this survey argues that nearly $49 \%$ of girls that are surveyed in Bihar say that they do not like studying. The article argues that perhaps they might think that earning livelihood is not

\footnotetext{
${ }^{38}$ Janssens, W. (2010). Women's Empowerment and the Creation of Social Capital in Indian Villages. World Development, 38(7), 975.

${ }^{39}$ Equity Foundation. (n.d.). A Baseline Survey on Girl's Education Program (Bihar) [Online]. Available from: http://equityasia.net/activity/A\%20Baseline $\% 20$ Survey\%20on $\% 20 \mathrm{G}$ irls\%E2\%80\%99\%20Education.pdf [Accessed 11 June 2012].

${ }^{40}$ Equity Foundation. (n.d.). A Baseline Survey on Girl's Education Program (Bihar). [Online]. Available from: http://equityasia.net/activity/A\%20Baseline $\% 20$ Survey $\% 20$ on $\% 20 \mathrm{G}$ irls $\%$ E2\%80\%99\%20Education.pdf [Accessed 11 June 2012].
} 
their responsibility. In the rural areas and the oppressed communities, girls are getting married in an early age, so the focus of the girl is to learn household works rather than focusing on education. ${ }^{41}$ Therefore, in terms of self-perception and self-confidence they think that education is not useful and they have interiorized their future as housewives. Parents have a great influence in girl's perceptions and aspirations.

We can see that girls face both indirect and direct power barriers. Parents' attitude towards girls is an indirect power barrier which is transmitted to the child since an early age and it conditions the vision she has of education. This affects the human resources which act as an indirect barrier as well. Girls interiorize what parents tell her since an early age. This also affects the economic barriers, which prevents the child from going to school. Therefore, the girl has not the opportunity to have an allocative resource or material resources which act as direct power barriers. ${ }^{42}$

\subsubsection{Input program}

It has been argued that the greatest and most significant impact of adult women's empowerment has been the impact that it has had on the lives of adolescents. The focus on adolescent girls has evolved over time. While the program aimed to impact and ensure girls' education and to issue appropriate and supportive educational interventions like the Mahila Shikshan Kendras ${ }^{43}$, the issue of girl's education did not emerge from the very beginning. In the initial stages of the program the principal focus was on mobilising and organising women. As the sanghas ${ }^{44}$ discussions began to centre more and more on the status of women, it began to emerge the question on how to change the future and, therefore, on how to teach younger generation to negotiate and challenge inequalities. ${ }^{45}$

\footnotetext{
${ }^{41}$ Equity Foundation. (n.d.). A Baseline Survey on Girl's Education

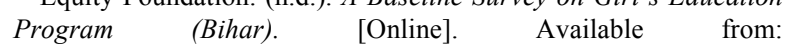
http://equityasia.net/activity/A\%20Baseline $\% 20$ Survey $\% 20$ on $\% 20 \mathrm{G}$ irls $\%$ E2\%80\%99\%20Education.pdf [Accessed 11 June 2012].

${ }^{42}$ Sadan, E. (2004). Chapter 3: A Theory of Empowerment. In: Sadan, E. ed. Empowerment and Community Practice. [Online]. Tel Aviv: Hakibutz Hameuchad. 156. Available from: http://www.mpow.org/ [Accessed 30 June 2012].

${ }^{43}$ Residential learning centers hereafter referred to as MSK.

${ }^{44}$ In the states of Bihar and Jharkhand sanghas are also known as samoohs.

${ }^{45}$ Jandhyala, K. (2003). Empowering Education: the Mahila Samakhya experience. UNESCO, 1-16.
}

As the Women Empowerment Approach of the Commission on Women and Development ${ }^{46}$ states, the program input is a whole range of strategies, resources and activities implemented. Here I will analyze the program input of Mahila Samakhya in Bihar for girl's education. In this case, they are based to empower mainly adolescents through education. The Methodological Guide Research argues that it is very important and necessary to determine the benefits of the program and how it improves economic, human and social resources. ${ }^{47}$

In Bihar, the Mahila Samakhya program was launched in 1992. In 1991, female literacy in Bihar was only 23 percent and 52 percent for men. In the 1991 census, about 80 percent of girls between the ages of 10 and 14 in Bihar state were not attending school. In many rural villages it was very difficult to find even a single literate woman. ${ }^{48}$

The program follows two strategies to empower women and adolescents that strive to remove gender based barriers of the mind, inculcated through experiences of discrimination and oppression in their own families and communities:

- A residential, curriculum based, learning center model which has the primary aim of mainstreaming drop out and girls who have never enrolled to school before. The Mahila Shikshan Kendrasa (MSK) and the Kasturba Gandhi Balika Vidyalayas are manifestations of this strategy. They both aim to remove social, cultural and systemic hurdles that deny girl's access to education. There are MSKs for prisoners and sexually abused girls with modifications regarding the different context.

- The formation of collectives where adolescents get the opportunity to reflect on their life, analyze issues and challenge patriarchal norms. The Kishori Mancha is a forum for girls while the Bala Sangham is

\footnotetext{
${ }^{46}$ Commission on Women and Development. (2007). The women empowerment approach, a methodological guide. [Online]. Vrouwen \& Ontwikkeling / Femmes \& Development. 19. Available from: http://www.atol.be/docs/publ/gender/women_empowerment_approa ch_CVO.pdf. [Accessed 22 June 2012].

47 Commission on Women and Development. (2007). The women empowerment approach, a methodological guide. [Online]. Vrouwen \& Ontwikkeling / Femmes \& Development. 19. Available from: http://www.atol.be/docs/publ/gender/women_empowerment_approa ch_CVO.pdf. [Accessed 22 June 2012].

${ }_{48}$ Mahila Samakhya - Bihar, Education for Women's Equality. [Online]. Available from: http://msbihar.org/introduction.html [Accessed 20 June 2012].
} 
formed by a group of girls and boys together. There is also the Jagjagi Kendras which complement last two models. It follows curricula and aims to mainstream drop out girls into school, but at the same time are deeply rooted in the community where it is based. $^{49}$

All the programs aim to influence adolescents in different ways and they are specialized in the different cases and situations, which permits to apply better programs in each context and to have better results. It aims to give more economic, human and socio-political resources. In terms of material or economic support, they help them with the buildings and equipment that enable them to empower. In terms of human resources, they give women knowledge and skills as well as the feeling of belonging to a group with whom they share the same values and with whom they develop their will and commitment. And in terms of social resources, they give women the capacity to support the organization, solidarity, will to empower other women and girls, etc.

\subsubsection{Impact on education}

The greatest impact of adult women's empowerment and education in Bihar has been the impact that it has had on the lives of adolescents. ${ }^{50}$ The impact of the program, as described by the Women Empowerment Approach from the Commission of Women and Development, uses the four aspects of empowerment: assets, knowledge, will and capacity. The impact of empowerment must be seen in relation to an improved quality of life for individuals and the building of social justice in terms of gender equality. ${ }^{51}$

In Bihar, most MSK students have been mainstreamed into schools or KGBVs. Acquiring knowledge, allows girls to know their rights and to demand education by themselves. Families visit often the MSK to see the

\footnotetext{
49 Purushothaman, S. (2010). Innovations towards Education for Empowerment, Grassroots Women's Movement. [Online]. Bangladore: Best Practices Foundation, 107-134. Available from: http://es.scribd.com/doc/46549386/Empowering-Adolescents-BestPractices-in-Mahila-Samakhya-Chapter-8 [Accessed 5 June 2012].

${ }^{50}$ Jandhyala, K. (2003). Empowering Education: the Mahila Samakhya experience. UNESCO, 1-16.

${ }^{51}$ Commission on Women and Development. (2007). The women empowerment approach, a methodological guide. [Online]. Available

http://www.atol.be/docs/publ/gender/women_empowerment_approa ch_CVO.pdf. [Accessed 22 June 2012].
}

progress of their daughters. When they see their confidence and progress, they are motivated to send their daughters to study further. Teachers also monitor girls to ensure that they will continue their education. $^{52}$ Many girls who have attended the MSK have refused to be married when they found out that they were minors and their parents have accepted their decision. $^{53}$

The Jagjagi Kendras have had the ability to mainstream large numbers of girls into regular schools. Even if the girl feels ready to attend school earlier, she enrolls. Families see the relevance of education when their daughters are able to fill forms, write applications and letters. Therefore, from the beginning a clear strategy is used to teach letter and application writing to girls in JJK, so that families can easily see the benefits of educating their daughters.

The indirect impact on education happens through the students who have already had a Mahila Samakhya experience. The Mahila Samakhya in Bihar has educated girls who are also agents of change because they have also been motivating their neighbors and sisters to empower themselves. Today in Bihar there are more girls applying for the MSK, for instance, than the places available. ${ }^{54}$ With literacy and knowledge, girls can influence their parents on issues concerning their own future. ${ }^{55}$

Besides from changing the girls' views, Mahila Samakya in Bihar also helps rural women to identify the main problems through sanghas faced in their daily lives and to learn to control their future and enjoy freedom and respect. These women have become more selfconfident and they have realized that their inability to read, write and count is a handicap when they have to deal with local government offices, banks, owners, the post office, schools, etc. Setting up a saving account,

\footnotetext{
52 Purushothaman, S. (2010). Innovations towards Education for Empowerment, Grassroots Women's Movement. [Online]. Bangladore: Best Practices Foundation, 107-134. Available from: http://es.scribd.com/doc/46549386/Empowering-Adolescents-BestPractices-in-Mahila-Samakhya-Chapter-8 [Accessed 5 June 2012]. ${ }^{53}$ Krishner, F. (2012). Bihar's Mahila Shikshan Kendras. Bihar Days [Online]. Available from: http://www.bihardays.com/columnists/archives-editorial-exeditor/bihars-mahila-shikshan-kendras/ [Accessed 6 June 2012].

${ }_{54}$ Purushothaman, S. (2010). Innovations towards Education for Empowerment, Grassroots Women's Movement. [Online]. Bangladore: Best Practices Foundation, 107-134. Available from: http://es.scribd.com/doc/46549386/Empowering-Adolescents-BestPractices-in-Mahila-Samakhya-Chapter-8 [Accessed 5 June 2012].

${ }_{55}$ Krishner, F. (2012). Bihar's Mahila Shikshan Kendras. Bihar Days [Online]. Available from: http://www.bihardays.com/columnists/archives-editorial-exeditor/bihars-mahila-shikshan-kendras/ [Accessed 6 June 2012].
} 
for instance, was impossible without literacy and numeracy skills. ${ }^{56}$

Therefore, through Mahila Samakhya process and activities, women became aware of their urgent need for literacy, numeracy, information and knowledge. Moreover, they wanted to ensure that their daughters would also have access to the same knowledge and skills. In this way, the process of women's empowerment created a strong demand from women and girls for education appropriate to their needs. Moreover, as we have already seen, as they gained greater access to education through Mahila Samakhya activities, they used their knowledge and skills to become more empowered and to improve the lives of their families and communities. Education and empowerment reinforce each other. ${ }^{57}$

According to some quantitative data, between 2009 and 2010, Bihar was the state in India with more MSK and KGBVs runned by Mahila Samakhya. ${ }^{58}$ Another source shows that, between 2009 and 2012, 10.191 girls and women graduated from MSKs across all states, with the state of Bihar in the leading position with 4.391 graduates. Therefore, we can see that Bihar is the state leading in progress in regards of education for women and girls through the MSK and KGVBs. ${ }^{59}$ In my opinion, quantitative data reveals little about the inequalities prevailing in the education system as well as the Mahila Samkahya program results in such a vast country. I think that first-hand girls' experience explains better the change of mindset and mobilization that increases girl's education. That is the reason why I will analyze in the next chapter personal experiences that can prove the effectiveness of the three-step empowerment process of this article's theoretical framework.

${ }^{56}$ Mahila Samakhya - Bihar, Education for Women's Equality. [Online]. Available from: http://msbihar.org/introduction.html [Accessed 20 June 2012].

57 Mahila Samakhya - Bihar, Education for Women's Equality. [Online]. Available from: http://msbihar.org/introduction.html [Accessed 20 June 2012].

${ }_{58}$ Purushothaman, S. (2010). Innovations towards Education for Empowerment, Grassroots Women's Movement. [Online]. Bangladore: Best Practices Foundation, 107-134. Available from: http://es.scribd.com/doc/46549386/Empowering-Adolescents-BestPractices-in-Mahila-Samakhya-Chapter-8 [Accessed 5 June 2012]. ${ }^{59}$ Purushothaman, S. (2010). Innovations towards Education for Empowerment, Grassroots Women's Movement. [Online]. Bangladore: Best Practices Foundation, 107-134. Available from: http://es.scribd.com/doc/46549386/Empowering-Adolescents-BestPractices-in-Mahila-Samakhya-Chapter-8 [Accessed 5 June 2012]. 


\section{Personal experiences with the Mahila Samakhya in Bihar}

This chapter will look through different girl's personal experiences with the Mahila Samakhya program upon more in-depth results over their lives and the community as a whole. The main theory applied will be the Elisheva's theory of empowerment.

\subsection{The story of Renu Kumari}

"You cannot go to school. Girls never go to school. You are supposed to tend to household chores and help me in my work." This is what the mother of Renu told her. She though Renu, her daughter of 10 years old, had to stay home instead of going to school. ${ }^{60}$ This is an example of an indirect power barrier because Renu has always heard the same argument from her mother who is a very influential person in her life. Therefore, the child has interiorized it as a reality. This is an authoritative resource imposed from society by its organization of social relations and life opportunities.

As Elisheva argues in her theory of empowerment, this is not a personal problem but rather a disempowering process that the system has imposed on the child. Regarding the theory, the mother powerlessness in terms of education and deciding about her future makes her adapt to the situation in order to survive. She thinks that staying home is the only future the girl has because they cannot decide or control about their future. And deciding to study is having control over one's self. That is why Renu ends up believing that education is worthless. ${ }^{61}$

Renu, therefore, never understood the importance of acquiring literacy skills. One day she met a friend from Bulakipur village, who told her about her experience in Jagjagi Kendra and the benefits of it. She told Renu that she could study at the Jagjagi Kendra and also learn vocational skills. Renu heard a different point of view of what she had always heard from her mother and this encouraged and inspired her to go to school

\footnotetext{
${ }^{60}$ Purushothaman, S. (2010). Innovations towards Education for Empowerment, Grassroots Women's Movement. [Online]. Bangladore: Best Practices Foundation, 107-134. Available from: http://es.scribd.com/doc/46549386/Empowering-Adolescents-BestPractices-in-Mahila-Samakhya-Chapter-8 [Accessed 5 June 2012].

${ }^{61}$ Sadan, E. (2004). Chapter 3: A Theory of Empowerment. In: Sadan, E. ed. Empowerment and Community Practice. [Online]. Tel Aviv: Hakibutz Hameuchad. 153. Available from: http://www.mpow.org/ [Accessed 30 June 2012].
}

and acquire knowledge. That is why she decided to bring her mother to the Jagjagi Kendra as well. ${ }^{62}$

The Jagjagi Kendra helped Renu's mother to loose fear about education and they advised her to bring Renu to the Jagjagi Kendra. Therefore, Renu had the opportunity to learn how to read stories, numeracy and write simple sentences. In the Jagjagi Kendra, she could share her problems and experiences and tackle challenges with other girls.

Then, Renu's parents decided to get her married. Renu placed her problem before her friends at the Jagjagi Kendra. This time, in contrast to the last time when she listened to her mother about the worthlessness of education, he opposed to get married. She wanted to continue studying and she did not want to ruin her life by marrying so early. Her parents were shocked that she was defying their decision and they did not want to cancel or postpone the marriage.

The Jagjagi Kendra itself and a couple of friends visited Renu's parents who finally cancelled the wedding. Renu was allowed to continue her studies and she entered the MSK in Dumra, Sitamarhi in 2004-05. After leaving the MSK, she trained girls at the Jagjagi Kendra. Renu wanted all the children of her village to study in mainstream schools. She also held coaching sessions for them. Many were inspired by Renu and joined schools.

Renu enrolled in a mainstream school after leaving MSK. And she paid her own education with the money she earned by sewing and teaching karate in schools. She successfully completed her class examinations in 2009. She works now for the Jagjagi Kendra in her village. She wants to be a teacher and she is now preparing for the exam. ${ }^{63}$

As the Women's Empowerment Approach from the Commission on Women and Development argues ${ }^{64}$,

\footnotetext{
${ }^{62}$ Purushothaman, S. (2010). Innovations towards Education for Empowerment, Grassroots Women's Movement. [Online]. Bangladore: Best Practices Foundation, 107-134. Available from: http://es.scribd.com/doc/46549386/Empowering-Adolescents-BestPractices-in-Mahila-Samakhya-Chapter-8 [Accessed 5 June 2012].

${ }^{63}$ All the story from: Purushothaman, S. (2010). Innovations towards Education for Empowerment, Grassroots Women's Movement. [Online]. Bangladore: Best Practices Foundation, 107-134. Available from: http://es.scribd.com/doc/46549386/EmpoweringAdolescents-Best-Practices-in-Mahila-Samakhya-Chapter-8 [Accessed 5 June 2012].

${ }^{64}$ Commission on Women and Development. (2007). The women empowerment approach, a methodological guide. [Online]. Vrouwen \& Ontwikkeling / Femmes \& Development. 19. Available from:
} 
the input program in the Jagjagi Kendra had specific objectives, strategies, resources and activities that empowered Renu. It improved her economic, human and social resources. She received, for instance, human resources such as training, support and coaching. She could share her problems and experiences and she tackled challenges with other girls. At the same time, teachers helped her at school to tackle these problems and at home, trying to reason with her parents. Jagjagi Kendra tried to empower the girl first through the collective, and it intervened as a collective when the girl could not manage with her environment. It is an advisory body as well as an intervening body.

Renu also got socio-political resources such as support for the organization, networking and lobbying. When she left the MSK, she trained girls at the Jagjagi Kendra. She wanted all the children to study like her; therefore, she acquired socio-political resources and skills. She held coaching sessions for them for threefour months and she inspired many girls. Finally, she acquired economic resources through her education and she paid her own education through the money sheearned by sewing and teaching.

Wanting all children to study and coaching other girls in the village, shows that her individual empowerment gave opportunities for collective empowerment for other girls afterwards. ${ }^{65}$ She participated in the empowerment of other girls. Therefore, in terms of the theory, empowerment process acted in the personal level but also in the mobilization, the social change. The change of mindset and mobilization were equally important for her empowerment.

\subsection{The story of Lalita Kumari}

In the Sitamarhi District, the village of Dusty located in the state of Bihar, Lalita Kurami overcame many obstacles to be educated. In Sitamarhi District, where Lalita lives, almost two-thirds of the population is living below the poverty line. Female literacy and girls' education have never been a high priority in the district. ${ }^{66}$

http://www.atol.be/docs/publ/gender/women_empowerment_approa ch_CVO.pdf. [Accessed 22 June 2012].

${ }_{65}$ See individual and collective empowerment: Sadan, E. (2004). Chapter 3: A Theory of Empowerment. In: Sadan, E. ed. Empowerment and Community Practice. [Online]. Tel Aviv: Hakibutz Hameuchad. 146-147. Available from: http://www.mpow.org/ [Accessed 30 June 2012].

${ }^{66}$ UNICEF. (2004). Transformation through education: The story of Lalita. [Online]. Available from:
Like many others in the village, Lalita's parents wanted her to get married at the age of 10. Since she wanted to learn, she attended the Jagjagi secretly. "I still remember the day my twin brother caught me going to school," recalls Lalita. "He beat me up since he was ashamed of the fact that I dared to study when none of the men in our family had ever attended school. My mother condoned his violence...I could not understand how mothers do not side with their daughters. ${ }^{67}$

As we have seen before, this is an indirect power barrier (authoritative resource). This time is the man who perceives that women should not study, and especially if men have not studied before her. Therefore, it has a perception and an image of women as below men and obliged to follow men's decisions. Lalita was still young to change her perception about herself and women in general. Her mother defended her son because she firmly believed what the son said. Therefore, she had already interiorized this role and adapted to her environment. The direct power barriers (allocative resources) were the allocation of resources, which is the lack of possibility of attending school in this case.

In 1997, the Mahila Samakhya program started a Mahila Shikshan Kendra where Lalita attended defying her parents. "In my village, I was doing nothing but cutting grass, fetching firewood, cleaning and cooking. In between, I used to attend the Jagjagi, but this was without my parents' knowledge," says Lalita. At the Mahila Shikshan Kendra Lalita and the other girls learned to read and write and other training. They were also taught cycling, karate, hygiene, health care and public speaking. ${ }^{68}$

After Mahila Shikshan Kendra, Lalita returned home with the skills that helped her start a tailoring shop. She asked for further education to the Mahila Shikshan Kendra and she was sponsored to acquire teaching skills in karate. Today Lalita teaches karate to girls in four Mahila Shikshan Kendra schools. She stated "I

\footnotetext{
http://www.unicef.org/infobycountry/india_lalita_education.html [Accessed 6 June 2012].

${ }^{67}$ UNICEF. (2004). Transformation through education: The story of Lalita. [Online]. Available from: http://www.unicef.org/infobycountry/india_lalita_education.html [Accessed 6 June 2012].

${ }^{68}$ UNICEF. (2004). Transformation through education: The story of Lalita. [Online]. Available from: http://www.unicef.org/infobycountry/india_lalita_education.html [Accessed 6 June 2012].
} 
want all the girls of the world to go to school like me and progress". ${ }^{69}$

Both her father and her mother changed their mentality through Lalita's experience. Her father stated: "Now I believe that every daughter has the potential, and I will tell everyone to think differently," while her mother also said: "Look at the respect that is being given to my daughter". ${ }^{70}$ As the Women Empowerment Approach argues, empowerment includes individual and collective abilities that offer a socio-political space as well as access and control of different means (resources, power, etc.). It argues that empowerment operates on two levels: in relation to its capacity for personal change and in relation to political and social change. ${ }^{71}$ Lalita, for instance, experienced a personal change within herself and her future and, at the same time, she contributed to the social change (mobilization) which was training other girls and changing her parent's views about education. Once more, this experience encouraged more education through education. It also improved her economic, social and human resources.

\subsection{The story of Shamima and Sahana}

Shamima, of 35 years old, from Muzaffarpur District in Bihar, grew up in a red light area where her life was restricted and education was seen as worthless. However, she wanted to go to school. Her sister was very supportive because she worked in an NGO. She encouraged Shamima and helped her to study. Her father encouraged them not to use a veil because he thought that it would be difficult for them to work wearing it. Initially people used to gossip but later this ended. Now she does no longer use a veil.

Shamima started a Jagjagi Kendra in the red light area after she finished school in Musheri block. In this area, when girls are older they are put into sex work. For

\footnotetext{
${ }^{69}$ UNICEF. (2004). Transformation through education: The story of Lalita. [Online]. Available from: http://www.unicef.org/infobycountry/india_lalita_education.html [Accessed 6 June 2012].

${ }^{70}$ UNICEF. (2004). Transformation through education: The story of Lalita. [Online]. Available from: http://www.unicef.org/infobycountry/india_lalita_education.html [Accessed 6 June 2012].

${ }_{71}$ Commission on Women and Development. (2007). The women empowerment approach, a methodological guide. [Online]. Vrouwen \& Ontwikkeling / Femmes \& Development. 11. Available from: http://www.atol.be/docs/publ/gender/women_empowerment_approa ch_CVO.pdf. [Accessed 22 June 2012].
}

instance, one student called Sahana was enrolled in JJK and wanted to study further but the community and her parents opposed it. As Shamima trusted in the community, she was able to get Sahana's mother's support to admit Sahana into an MSK. From the MSK Sahana further went on to study in the KGBV. Over the years, she too has mobilized many girls to study in MSK. $^{72}$

In this case, Shamima grows in a positive environment for education without direct or indirect barriers. Shamima is lucky enough to go to school and that helps to avoid sex-slavery. Once more, we can see cases of individual empowerment that change one's life but also change society. Shamima's sister influences Shamima, Shamima's experience influences Sahana and Sahana's experience helped to mobilize many girls to study like her afterwards. This is a circle that helps to keep increasing education among girls.

Therefore, they gained greater access to education through Mahila Samakhya activities; they used their knowledge and skills to become more empowered and to improve the lives of their families and communities.

\subsection{Overall analysis}

All these stories follow the Elisheva's description of empowerment process $^{73}$ to change the girl's mindset and to encourage her mobilization. First, the empowerment process that changes their view starts with the sense of frustration. In Renu's case, she realizes that the resources necessary to make her aspirations come true are beyond her reach. That is why she wants to convince her mother and she brings her to the Kendra, therefore, she has the minimal ability and resources that enable her to organize activity and a minimum of social legitimation which is the opportunity to bring her mother to the Kendra.

Having the will to go to study is already the first outcome of the empowerment process. Another outcome of mindset change through empowerment is having the critical consciousness of the existing situation and that

\footnotetext{
72 Purushothaman, S. (2010). Innovations towards Education for Empowerment, Grassroots Women's Movement. [Online]. Bangladore: Best Practices Foundation, 121. Available from: http://es.scribd.com/doc/46549386/Empowering-Adolescents-BestPractices-in-Mahila-Samakhya-Chapter-8 [Accessed 5 June 2012]. ${ }_{73}$ Sadan, E. (2004). Chapter 3: A Theory of Empowerment. In: Sadan, E. ed. Empowerment and Community Practice. [Online]. Tel Aviv: Hakibutz Hameuchad. 151-152. Available from: http://www.mpow.org/ [Accessed 30 June 2012].
} 
she has the right to express aspirations and the ability to define them. This is the case of Lalita Kumari's experience, since she decided to study secretly and independently from what her family believed. She also believed in her own ability to achieve outcomes. Then, it is already an achievement and a change in terms of sense of individual ability to achieve outcomes.

As Elisheva argues, self-efficacy may become collective efficacy if it gets translated into the community's ability to organize itself to influence the environment. In most of the cases, Lalita, Renu, Shamima and Sahana, they influenced their environment by their own empowerment and self-efficacy through a collective effort. They succeeded in mobilizing resources to continue the process, including resources of knowledge about organizing and setting up community organizations. This is an outcome that indicates that the empowerment process has established itself. As Elisheva argues this is a proof that the people have secured for themselves an ongoing ability to achieve outcomes: to control their lives, to participate in decision making and to influence the environment. They have already changed their mindset and they are contributing to increase education among girls, through their own education and consciousness about its importance. ${ }^{74}$

In all 4 personal experiences with the Mahila Samakhya program we have seen that the result of education is an increase in the formal education. Receiving education permitted some of them to continue to the mainstream education, to build their own business, etc. The outcomes of each experience are different. However, most of them continued supporting the kendras and collaborated in the education process. It shows the impact of the Mahila Samakhya program on trust and cooperation. Seeing these cases, I argue that the Mahila Samakhya program creates a spillover effect on participants and nonparticipant, respectively in program villages. If the members of Mahila Samakhya initiate collective action in the village, this might induce others to join in the activity as well. In addition, increased cooperation might provide sufficient positive experiences to increase trust within other communities and spread. In other words, the impact of the Mahila Samakhya pro-

\footnotetext{
${ }^{74}$ Sadan, E. (2004). Chapter 3: A Theory of Empowerment. In: Sadan, E. ed. Empowerment and Community Practice. [Online]. Tel Aviv: Hakibutz Hameuchad. 152. Available from: http://www.mpow.org/ [Accessed 30 June 2012].
}

gram might reach other villages through a village's experience.

Through the empowerment process, the girls acquired the 4 main powers of empowerment. They acquired "power over" her parents and her life, from a position of subordination to a domination status. They got the "power within" such as self-awareness, self-esteem and identity that lead to "power to" make decisions, as to continue studying, pay their own education (economic means) or build a business. They had "power with" the community where they studied (Jagjagi Kendra, Kishori Mancha, etc.), understanding other girls and collaborating to the collective empowerment and achieving common objectives training and encouraging other girls. This is translated as greater assets which are economic powers (power to), knowledge or skills that enabled them to make the most of their opportunities (power to), will and strength to have more selfconfidence to control their future (power within) and capacity to make decisions for herself but also to help others (power with). All this encouraged them to go from a passive situation to a domination situation (power over).

All these statements and stories illustrate just a few of the cases that have been brought in terms of education in several districts of Bihar covering through Mahila Samakhya program. ${ }^{75}$ The official website of Mahila Samkahya program in Bihar assures that thousands of women have benefited through Mahila Samakhya interventions in education, health, economic initiatives, governance, legal literacy and other issues crucial in the growth and development of women. Young girls and mothers have gone beyond the basic knowledge of reading, writing and calculating numbers, towards becoming an integral part of the decision-making processes within their homes and in the society. And all the different institutions of the Mahila Samakhya program have played a significant role in this empowerment process. ${ }^{76}$

\footnotetext{
${ }^{75}$ More stories to be read in both: Krishner, F. (2008). Frank Opinions [Online]. Mahila Samakhya in Bihar: girls, education, social change. Available from: http://frankop.blogspot.ch/2008/04/women-education-social-changejaiman.html [Accessed 21 June 2012] and Jandhyala, K. (2003) and Empowering Education: the Mahila Samakhya experience. UNESCO, 1-16.

${ }^{76}$ Mahila Samakhya - Bihar, Education for Women's Equality. [Online]. Available from: http://msbihar.org/introduction.html [Accessed 20 June 2012].
} 


\section{Conclusion}

This article analyzed the change of mindset and mobilization through the empowerment education's program Mahila Samakhya in the Indian state of Bihar as a way to increase girl's education.

In order to introduce the topic, I have first explained my theoretical framework which consists of a Methodological Guide of Women Empowerment and the Elisheva Sadan's Empowerment Theory. Then, I have made a description of the Indian Government's policies and the influence of women's movement in promoting women's education and a brief description of the gender gap that still exists in India. Further, I have introduced very broadly the Mahila Samakhya program as an alternative form of education for women in rural areas and discriminated communities. The aim of all these chapters has been to introduce the topic of the Mahila Samakahya program before proving my argument.

Then, I have chosen a particular case study, Bihar, to show how the Mahila Samakhya works in terms of education for women and girls in the rural and disadvantaged communities. Through a three-step analysis described in the Methodological Guide of Women Empowerment, I have gone through the different stages of the program to see how it works and to prove the results it has on girl's education. We have seen through

the baseline stage the initial situation of most girls in Bihar, the barriers they encounter in formal education. We have seen that boys and girls do not have the same opportunities in education.

On the one hand, girls are seen as the ones that leave the house to get married and never come back, therefore, they have to learn housework. On the other hand, boys are seen as a good investment to study because they will be the ones that earn money for the family in the future. Most of the girls find education worthless, because they have been inculcated this idea since they were young. Through the Elisheva's empowerment theory we have seen that these are indirect and direct power barriers for girls in education.

Through the second stage, the input program, we have seen that the Mahila Samakhya program in Bihar helps rural women to identify the main problems they have in their daily lives and learn to control their future as well as acquire basic skills such as reading, writing and counting. With these improvements they realize about the importance these skills have in their daily lives. This influences their daughters, because they might take difficult decisions such as bringing the child to school and avoiding child marriage because they want their daughter to be also educated. This has created a demand for education appropriate to the needs of women and also girls. This is a change of mindset of women that influences girls. Therefore, as Elisheva's empowerment theory argues, collective empowerment of women gives opportunities to individual empowerment and vice versa.

Further, we have also seen the specific initiatives within the Mahila Samakhya program for girls' education in Bihar that principally aim to mainstream girls to regular schools. Therefore, there is also a change of mindset of young girls. We have seen that within the Mahila Samakhya program there are different programs for special needs for girls and women (residential and non-residential schools, curriculum based and forum based centers, for sexually abused girls, for semiliterate women and girls, etc.). And all of them lead to regular schooling. It has been seen that girls can influence their parents on issues concerning their own future and the worthiness of their education through daily results and facing daily problems. Then, these centers do play a vital role in bridging the gap for gender equality in education, by ensuring access and creating awareness in the community and among the girls about the importance of education. They both aim to remove social, cultural and systemic hurdles that deny girl's access to education and to prepare them for regular education.

In the final stage where the results are described, we can see that in Bihar there has been much done and it is the leading state for girls and women graduated from MSKs among all states in India. Therefore, Bihar is the leading state in progress in regards of education for women and girls through the MSK and KGVBs. Anyway, I have not totally relied in quantitative data and I have analyzed more personal experiences applying the theory and proving the change of mindset and mobilization experienced mostly by girls. I have analyzed 4 different personal experiences.

Through the stories we have seen the empowerment process described by Elisheva, from the frustration stage since the fully establishment of the 
empowerment. Therefore, this article proves the evolution through the theoretical framework from a state of powerlessness to a position of control of women's and girls' lives. It has proven that the Mahila Samakhya program in Bihar has empowered many girls and women that have also empowered other girls. That means that both collective empowerments contributed to individual empowerment and the other way around. We have seen how they have influenced their personal life and how they also influenced the environment, the two aspects of empowerment.

The article has also argued that this change of mindset creates mobilization and increases education for girls. We have seen that the Mahila Samakhya program creates a spillover effect on participants and nonparticipant, in the villages where the program has been implemented. If the members of Mahila Samakhya suc- cessfully initiate collective action this triggers more education. In addition, increased cooperation might provide positive experiences regarding that instigate the trust of other communities. In other words, the impact of the Mahila Samakhya program on social capital might reach beyond the participants to reach other villages as well. That is why we have considered that qualitative data can show as greater results than quantitative one. Quantitative data shows us only a number that we cannot associate with anything (how many illiterates, how many enrolled, etc.). Qualitative data show us better the nuances, the complexity, the canvas of the different changes. It also shows us that one single change in one individual is considered a success, because it marks the beginning of a new era of change of the entire community.

\section{References}

- Batliwala, S. (2007). Taking the Power out of Empowerment: An Experiential Account. Development in Practice, 17(4/5), 557-565.

- Commission on Women and Development. (2007). The women empowerment approach, a methodological guide. [Online]. Vrouwen \& Ontwikkeling / Femmes \& Development. 143. Available from: http://www.atol.be/docs/publ/gender/wo men_empowerment_approach_CVO.pdf. [Accessed 22 June 2012].

- Equity Foundation. (n.d.). A Baseline Survey on Girl's Education Program (Bihar). [Online]. Available from: http: / / equityasia.net/activity/A\%20Baseline \%20Survey\%20on\%20Girls\%E2\%80\%99\%20 Education.pdf [Accessed 11 June 2012].

- Govinda, R. (2006). The Politics of the Marginalised: Dalits and Women's Activism in India. Gender and Development, 14 (2), 181-190.

- Jain, S. (2003). Gender equality in education. Community based initiatives in India. [Online]. Education for All Global Monitoring Report 2003/2004. Available from: http://ddpext.worldbank.org/EdStats/INDgmrpap03a.p df [Accessed 3 June 2012].

- Jandhyala, K. (2003). Empowering Education: the Mahila Samakhya experience. UNESCO, 1 16.

- Janssens, W. (2010). Women's Empowerment and the Creation of Social Capital in
Capital in Indian Villages. World Development, 38(7), 974-988.

- Krishner, F. (2012). Bihar's Mahila Shikshan Kendras. Bihar Days [Online]. Available from: http://www.bihardays.com/columnists/arch ives-editorial-ex-editor/bihars-mahilashikshan-kendras/ [Accessed 6 June 2012].

- Krishner, F. (2008). Frank Opinions [Online]. Mahila Samakhya in Bihar: girls, education, social change. Available from: http://frankop.blogspot.ch/2008/04/women-educationsocial-change-jaiman.html [Accessed 21 June 2012].

- Mahila Samakhya - Bihar, Education for Women's Equality. [Online]. Available from: http://msbihar.org/introduction.html [Accessed 20 June 2012].

- Mahila Samakhya (Education for Women's Equality) Programme Ministry of Human Resource Development (Department of Elementary Education \& Literacy). [Online]. Available from: http: / / www.google.com/url?sa $=\mathrm{t} \& \mathrm{rct}=\mathrm{j} \& \mathrm{q}$ $=$ mahila $\% 20$ samakhya $\% 20$ (education $\% 20$ for $\% 20$ women $\%$ E2\%80\%99s\%20equality) $\% 20$ p ro-

gramme $\&$ source $={ }_{w e b \& c d}=1 \&$ sqi $=2 \&$ ved $=0$ CF0QFjAA\&url=http\%3A\%2F\%2Fssa.nic.in $\% 2$ Fgirls-education $\% 2$ Fmahila-samakhyascheme $\% 2$ F10THPLAN-

MSL.pdf\&ei=OTvST7OlO4m3hAe03YjIAw\& 
usg=AFQjCNEi_TD4JH9eBDmy03ONBNIH m9u0vQ [Accessed 8 June 2012].

- Oxaal, Z. and Baden, S. (1997). Gender and empowerment: definitions, approaches and implications for policy [Online]. University of Sussex: Bridge (development-gender). Available from: http: / / generoyambiente.com/arcangel2/doc umentos/376.pdf [Accessed 21 June 2012].

- Patel, I. (1998). The contemporary women's movement and women's education in India. International Review Education, 44(2-3), 155175.

- Purushothaman, S. (2010). Innovations towards Education for Empowerment, Grassroots Women's Movement. [Online]. Bangladore: Best Practices Foundation, 107-134. Available from: http: / / es.scribd.com/doc/46549386/Empo wering-Adolescents-Best-Practices-in-MahilaSamakhya-Chapter-8 [Accessed 5 June 2012].

- Ramachandran, V. (2009). Education for all mid decade assessment. Towards Gender Equality in Education. [Online]. New Delhi: National University of Educational Planning and Administration New Delhi. Available from: http: / / www.educationforallinindia.com/To wards-Gender-Equality-in-Education-1.pdf [Accessed 15 June 2012].

- Sadan, E. (2004). Chapter 3: A Theory of Empowerment. In: Sadan, E. ed. Empowerment and Community Practice. [Online]. Tel Aviv: Hakibutz Hameuchad. 137-169. Available from: http://www.mpow.org/ [Accessed 30 June 2012].
- Sen, S. (2000). Towards a Feminist Politics? The Indian Women's Movement in Historical Perspective. [Online]. Working Paper Series No. 9. The World Bank Development Research Group. Available from: http: / / www google.com / url?sa =t\&rct $=$ j\&q $=$ towards $\% 20$ feminist $\% 20$ politics\&source $={ }_{\mathrm{w}}$ eb\&cd $=1 \&$ ved $=0 \mathrm{CFcQFjAA} \& u r l=$ http $\% 3 \mathrm{~A} \%$ 2F\%2Fciteseerx.ist.psu.edu\%2Fviewdoc $\% 2$ Fdown-

load\%3Fdoi\%3D10.1.1.195.9810\%26rep\%3 Drep1\%26type\%3Dpdf\&ei=iKzIT7LTHcOX OqyzsAY\&usg=AFQjCNEESalc1jHZUCPYn wnEbbt9efTEGA [Accessed 20 June 2012].

- Sharma, K. (1989). Shared aspirations, fragmented realities contemporary women's movement in India its dialects and dilemmas [Online]. Available from: http: / /www.cwds.ac.in/OCPaper/SharedAs pirationsKS.pdf. [Accessed 26 February 2012].

- Subramaniam, M. (2011). Grassroots groups and poor women's empowerment in rural India. International Sociology. 27(1) 72-95.

- UNICEF. (2004). Transformation through education: The story of Lalita. [Online]. Available from:

http: / / www.unicef.org/infobycountry/india _lalita_education.html [Accessed 6 June 2012].

\section{Forma de Citación}

BARBERILLO NUALART, Gemma: The Mahila Samakhya program: Empowering education for women's equality in Indian disadvantaged communities and rural areas. Revista Communication Papers, $\mathrm{N}^{\circ} 1$, páginas 115 a 132. Departamento de Filología y Comunicación de la Universidad de Girona. Recuperado el de de 2 de: http://www.communicationpapers.es 
